\title{
Pengaruh Implementasi Total Quality Management pada Kinerja Manajerial Perusahaan Otobus Pariwisata di Kota Denpasar
}

\author{
I Gusti Ayu Tri Bhuwana Dewi ${ }^{1}$ \\ Fakultas Ekonomi dan Bisnis \\ Universitas Udayana, Indonesia
}

\author{
I Gusti Ayu Made Asri Dwija Putri² \\ Fakultas Ekonomi dan Bisnis \\ Universitas Udayana, Indonesia
}

\begin{abstract}
Surel : gegdessy@gmail.com
\section{ABSTRAK}

Total Quality Management (TQM) merupakan konsep manajemen modern yang berusaha untuk memberikan respon secara tepat terhadap perubahan yang ada. Tujuan penelitian ini adalah untuk mengetahui pengaruh aspek pada TQM yaitu fokus pada pelanggan, obsesi terhadap kualitas, perbaikan berkelanjutan serta keterlibatan dan pemberdayaan karyawan terhadap kinerja manajerial PO Bus Pariwisata. Responden dalam penelitian ini yaitu seluruh pegawai dari 8 perusahaan $\mathrm{PO}$ bus pariwisata di Kota Denpasar yang ditentukan dengan metode non-probability sampling yaitu sampling jenuh. Pengumpulan data dilakukan dengan kuesioner dengan teknik analisis data yaitu regresi linear berganda. Berdasarkan hasil analisis menunjukkan aspek-aspek TQM yaitu fokus pada pelanggan, obsesi terhadap kualitas, perbaikan berkelanjutan serta keterlibatan dan pemberdayaan karyawan berpengaruh positif dan signifikan terhadap kinerja manajerial pada PO bus pariwisata di Kota Denpasar.
\end{abstract}

Kata Kunci: Teori Organisasi; Total Quality Management; Kinerja Manajerial.

\section{The Effect of Implementation of Total Quality} Management on Managerial Performance in the Tourism Otobus Company in Denpasar City

\section{ABSTRACT}

Total Quality Management (TQM) is a modern management concept that seeks to provide an appropriate response to existing changes. The purpose of this study was to determine the effect of aspects on TQM, namely focus on customers, obsession with quality, continuous improvement and employee involvement and empowerment on the managerial performance of tourism OC. Respondents in this study were all employees of 8 tourism otobus companies in Denpasar that were determined by the non-probability sampling method, namely saturated sampling. Data collection is done by questionnaire with data analysis techniques, namely multiple linear regression. Based on the results of the analysis shows aspects of TQM namely customer focus, obsession with quality, continuous improvement and employee involvement and empowerment have a positive and significant effect on managerial performance on tourism OCs in Denpasar.

Keywords: Organizational Theory; Total Quality Management; Managerial Performance.

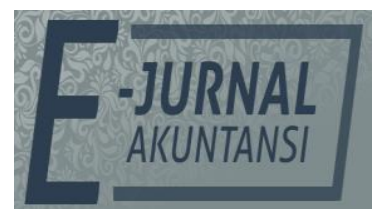

e-ISSN 2302-8556

Vol. 30 No. 10

Denpasar, Oktober 2020

Hal. 2487-2499

DOI:

10.24843/EJA.2020.v30.i10.p04

PENGUTIPAN:

Dewi, I G. A. T. B. \& Asri, I

G. A. M. (2020). Pengaruh

Implementasi Total Quality Management pada Kinerja

Manajerial Perusahaan

Otobus Pariwisata di Kota

Denpasar. E-Jurnal

Akuntansi, 30(10), 2487- 2499

RIWAYAT ARTIKEL:

Artikel Masuk:

7 Mei 2020

Artikel Diterima:

16 Juli 2020

Artikel dapat diakses : https://ojs.unud.ac.id/index.php/Akuntansi/index 


\section{PENDAHULUAN}

Persaingan yang sangat ketat ini memaksa perusahaan untuk menjadi yang terbaik untuk dapat bertahan atau sebagai pemenang dalam persaingan. Cara yang dapat ditempuh oleh perusahaan untuk dapat menjadi yang terbaik adalah dengan meningkatkan kinerja perusahaan melalui perbaikan secara berkesinambungan. Kinerja perusahaan yaitu output atau hasil yang dihasilkan kemudian diukur dan dibandingkan dengan output atau hasil yang diharapkan oleh perusahaan menurut (Prayhoego \& Devie, 2013). Dalam perkembangan akuntansi manajemen beberapa isu kontemporer dalam teknik-teknik manajemen mulai diterapkan, seperti metode just in time (JIT), total quality management (TQM), target costing, dan orientasi pelanggan (Putri, 2008). Salah satu alat manajemen yang bisa digunakan untuk meningkatkan kinerja adalah Total Quality Management (TQM). Total Quality Management (TQM) merupakan suatu konsep manajemen modern yang berusaha untuk memberikan respon secara tepat terhadap setiap perubahan yang ada, baik yang didorong oleh kekuatan eksternal maupun internal organisasi (Pratama \& Maghfiroh, 2016).

Penerapan TQM membutuhkan sistem akuntansi manajemen sebagai mekanisme untuk memotivasi dan mempengaruhi perilaku karyawan dalam berbagai cara yang memaksimalkan kesejahteraan organisasi dan karyawan. Sistem akuntansi manajemen yang digunakan dalam penelitian ini meliputi sistem pengukuran kinerja manajerial perusahaan. Kinerja manajerial merupakan salah satu cara untuk menentukan apakah tujuan perusahaan yang telah ditentukan sebelumnya tercapai atau tidak. Kinerja manajerial yang maksimal dapat diperoleh dengan memanfaatkan sistem pengendalian manajemen untuk memotivasi seluruh personel perusahaan agar mampu mewujudkan tujuan perusahaan. Kenyataannya meskipun perusahaan telah menerapkan sistem pengendalian manajemen, tidak juga dapat menghindarkan manajerial berada di tingkatan kinerja yang rendah. Hal tersebut dapat disebabkan oleh adanya ketergantungan akan sistem akuntansi manajemen perusahaan yang gagal dalam penentuan sasaran yang tepat, ukuran kinerja yang salah maupun sistem reward yang diberikan tidak tepat (Swari \& Wirasedana, 2017).

Industri pariwisata membantu menggerakkan perekonomian serta menyediakan lapangan pekerjaan. Tidak salah jika dikatakan bahwa pariwisata adalah sebagai lokomotif yang mendorong sektor lainnya yang terkait. Salah satu usaha yang sangat terkait dengan kepariwisataan adalah transportasi. Transportasi merupakan sarana pokok yang harus ada dalam kegiatan kepariwisataan. Meningkatnya permintaan akan jasa transportasi bus sangat berpengaruh terhadap perkembangan jumlah perusahaan bus yang beroperasi di Bali, dan tentu saja hal ini dapat menimbulkan persaingan yang semakin ketat. Untuk dapat bertahan ditengah persaingan yang ketat, khususnya dibidang bisnis pelayanan jasa transportasi bus, Perusahaan otobus (PO) harus dapat menjaga kinerja manajerial perusahaan, dengan menerapkan TQM.

Berdasarkan data terakhir yang diperoleh dari organisasi angkutan darat (Organda) tahun 2019 perkembangan jumlah PO bus pariwisata di kota Denpasar terus mengalami penurunan (berdasarkan perpanjangan ijin operasi) seperti tersaji pada Tabel 1. 
Tabel 1. Perkembangan Jumlah Perusahaan Otobus Pariwisata di Kota Denpasar selama 5 Tahun (2014-2018)

\begin{tabular}{crrr}
\hline Tahun & Jumlah & Perkembangan & \\
\hline 2014 & 12 & 0 \\
2015 & 10 & 16,7 \\
2016 & 10 & 16,7 \\
2017 & 9 & 10,0 \\
2018 & 8 & 22,2 \\
\hline
\end{tabular}

Sumber: Organda Kota Denpasar, 2019

Berdasarkan Tabel 1, dapat diketahui terjadinya penurunan rata-rata 13,12 persen selama lima tahun (2014-2018). Penurunan ini mengindikasikan bahwa telah terjadi kesalahan mengelola perusahaan otobus, sehingga peneliti tertarik untuk melakukan penelitian lebih lanjut berkaitan dengan penerapan TQM terhadap kinerja manajerial. Dalam penelitian Singkoh et al. (2018) menunjukan bahwa kerja sama tim (X1), pendidikan dan pelatihan (X2), perbaikan sistem secara berkesinambungan (X3), obsesi terhadap kualitas (X4) dan fokus pada pelanggan (X5) secara positif signifikan berpengaruh terhadap terhadap kinerja manajerial $(Y)$. Kualitas merupakan strategi yang dapat memberikan konstribusi yang maksimal dalam pemberian layanan dan juga harus mempunyai kinerja organisasi yang baik untuk biasa mencapai tujuan dari puskesmas serta dapat meningkatkan setiap aspek di dalam puskesmas. Hasil penelitian Muhamad (2015) menunjukan bahwa TQM berpengaruh secara positif signifikan terhadap kinerja manajerial.

Dalam studi yang dilakukan oleh Oprime et al. (2012) menyimpulkan bahwa keberhasilan perbaikan berkelanjutan dalam suatu perusahaan tergantung pada pelatihan karyawan untuk menyelesaikan masalah, insentif untuk karyawan dan ide yang berdampak pada perbaikan, komunikasi tatap muka, dan kunjungan ke toko, serta perbaikan sistem secara berkelanjutan berkontribusi pada peningkatan produktivitas, kualitas, waktu, efisiensi biaya, kepuasan pelanggan, dan pembentukan keterampilan pekerja untuk memecahkan masalah. Perbaikan berkelanjutan akan memiliki dampak positif pada proses bisnis internal kinerja, termasuk produksi, efisiensi biaya, kualitas, ketepatan waktu dan ketepatan pengiriman barang dan jasa kepada pelanggan. Hal tersebut akan meningkatkan kinerja pelanggan dan akhirnya meningkatkan kinerja manajerial perusahaan. Singkatnya, perbaikan terus menerus akan meningkatkan organisasi kinerja. Perbaikan berkelanjutan juga berpengaruh positif signifikan terhadap kinerja manajerial dapat diukur dengan peningkatan pengembalian tentang investasi (Heavey et al., 2014).

Penelitian yang dilakukan oleh Parwitasari \& Wirasedana (2018) dengan judul pengaruh penerapan total quality management, komitmen organisasi pada kinerja manajerial dengan reward sebagai variabel moderasi, menyimpulkan bahwa total quality management berpengaruh positif signifikan pada kinerja manajerial. Penelitian tersebut merupakan acuan bagi peneliti untuk mengembangkan penelitian pada perusahaan otobus bus pariwisata di Kota Denpasar. Manajemen PO Bus Pariwisata dituntut untuk memperkuat posisinya dalam persaingan dengan memperkuat basis persaingannya. Untuk memperkuat basis persaingan tersebut perusahaan harus memiliki alat, metode atau prinsip- 
prinsip yang akurat. Penerapan TQM bagi perusahaan diharapkan dapat meningkatkan kepuasan konsumen melalui aspek-aspek yang ada pada TQM yang menjadi fokus pada penelitian ini yaitu fokus pada pelanggan, obsesi terhadap kualitas, perbaikan berkelanjutan serta keterlibatan dan pemberdayaan karyawan terhadap kinerja manajerial.

Kepuasan pelanggan merupakan salah satu indikator penting untuk mengukur kesehatan suatu perusahaan. Karena terdapat korelasi yang sangat kuat antara tingginya tingkat kepuasan pelanggan dan tingginya tingkat loyalitas mereka, yang pada akhirnya dapat meningkatkan profitabilitas perusahaan (Rangkuti, 2010). Pelanggan merupakan orang yang harus dilayani oleh penjual, baik jasa maupun barang. Setiap organisasi perusahaan harus mengetahui, mengidentifikasi, dan menganalisis kebutuhan dan harapan pelanggan agar bisa memuaskannya. Dimana produk/jasa yang dibuat atau diberikan haruslah sesuai dengan keinginan para pelanggan. Dalam pendekatan TQM, kualitas ditentukan oleh pelanggan. Oleh karena itu hanya dengan memahami proses dan pelanggan maka organisasi dapat menyadari dan menghargai makna kualitas. Semua usaha manajemen dalam TQM diarahkan pada satu tujuan utama yaitu terciptanya kepuasan pelanggan. Sehingga dengan adanya implementasi fokus pada pelanggan akan meningkatkan kinerja manajerial. Efendi \& Mandala (2018) dalam penelitianya menemukan variabel fokus pada pelanggan berpengaruh signifikan terhadap kinerja manajerial perusahaan, hal ini sejalan dengan penelitian Kinasih (2017) yang menemukan bahwa fokus pada pelanggan berpengaruh positif terhadap kinerja manajerial perusahaan, sehingga semakin tinggi tingkat fokus pada pelanggan maka semakin tinggi kinerja manajerial perusahaan. Berdasarkan uraian tersebut, hipotesis yang dapat diajukan adalah sebagai berikut.

$\mathrm{H}_{1}$ : Fokus pada pelanggan berpengaruh positif terhadap kinerja manajerial perusahaan.

Obsesi terhadap kualitas merupakan sikap tidak pernah puas akan kualitas dari produk yang dihasilkan. Peningkatan kualitas produk juga dapat mengurangi biaya kualitas yang dapat menurunkan laba. Apabila sikap ini dapat ditanamkan di benak para manajer, maka kinerja para manajer akan meningkat karena mereka ingin tetap menghasilkan produk yang bermutu tinggi. Penelitian yang dilakukan oleh Irmadhani et al. (2019) yang menyatakan bahwa obsesi terhadap kualitas berpengaruh terhadap kepuasan pelanggan. Jadi semakin besar obsesi pada kualitas maka semakin tinggi kinerja manajerial perusahaanya. Berdasarkan uraian diatas dapat dirumuskan hipotesis sebagai berikut.

$\mathrm{H}_{2}$ : Obsesi pada kualitas berpengaruh positif terhadap kinerja manajerial perusahaan.

Perbaikan secara terus-menerus harus dilakukan perusahaan seiring dengan perkembangan informasi dan kebutuhan pelanggan. Perbaikan secara berkala di segala bidang yang rutin dilakukan perusahaan dapat meningkatkan kinerja manajerial. Peningkatan kinerja manajerial pada akhirnya dapat meningkatkan kualitas produk yang berujung pada peningkatan laba perusahaan dan akan berdampak langsung terhadap kinerja manajerial perusahaan. Almansour (2012) melakukan penelitian yang bertujuan mencari jawaban apakah penerapan TQM meningkatkan kinerja manajerial UKM di 
Yordania. Hasil penelitian menyimpulkan bahwa pengaruh TQM terutama orientasi perbaikan berkelanjutan memberikan dampak yang baik terhadap kinerja perusahaan. Perbaikan berkelanjutan berpengaruh positif yang signifikan terhadap kinerja manajerial, dapat diukur dengan peningkatan pengembalian tentang investasi (Heavey et al., 2014). Hasil penelitian yang dilakukan oleh (Lamato et al., 2017) juga memperoleh hasil yang sama yaitu perbaikan sistem secara berkesinambungan berpengaruh positif terhadap kinerja manajerial. Berdasarkan uraian tersebut, maka dapat dibuat hipotesis sebagai berikut.

$\mathrm{H}_{3}$ : Perbaikan sistem secara berkesinambungan berpengaruh positif terhadap kinerja manajerial perusahaan.

Pemberdayaan merupakan kunci utama dalam motivasi dan produktivitas, seorang karyawan yang merasa dirinya dihargai dan memiliki kontribusi akan berkembang secara pribadi dan professional sehingga kontribusinya bagi organisasi dapat dimaksimalkan. Keterlibatan dan pemberdayaan karyawan mengarah pada karyawan untuk membantu dirinya sendiri, saling membentuk, dan membantu perusahaan. Sehingga dengan adanya implementasi keterlibatan dan pemberdayaan karyawan akan meningkatkan kinerja manajerial. Sejalan dengan hasil penelitian yang dilakukan oleh (Lamato et al., 2017) mengungkapkan bahwa keterlibatan dan pemberdayaan karyawan berpengaruh positif terhadap kinerja manajerial. Maka pemberdayaan karyawan sangat penting dan memberikan kesempatan lebih banyak kepada karyawan untuk mengembangkan kreativitas, fleksibilitas dan otonomi atas pekerjaannya. Pemberdayaan terhadap karyawan akan membuat seseorang merasa penting. Hasil penelitian yang sama juga diperoleh Kinasih, (2017); Muhamad (2015). Oleh karena itu, pemberdayaan karyawan juga dapat memperkuat TQM terhadap tingkat kinerja perusahaan Psomas et al. (2014). Berdasarkan uraian tersebut, maka dapat dibuat hipotesis.

$\mathrm{H}_{4}$ : Keterlibatan dan pemberdayaan karyawan berpengaruh positif terhadap kinerja manajerial perusahaan.

\section{METODE PENELITIAN}

Penelitian ini menggunakan pendekatan kuantitatif yang berbentuk asosiatif. Objek penelitian ini adalah pengaruh 4 karakteristik yang ada pada TQM yaitu fokus pada pelanggan, obsesi terhadap kualitas, perbaikan sistem secara berkesinambungan, keterlibatan dan pemberdayaan karyawan serta kinerja manajerial. Jenis data yang digunakan dalam penelitian ini adalah data kualitatif yaitu gambaran umum tentang Perusahaan Otobus Pariwisata dan data kuantitatif yaitu jumlah perusahaan otobus pariwisata di kota Denpasar.

Populasi dalam penelitian ini adalah seluruh perusahaan otobus pariwista yang ada di kota Denpasar yang berjumlah 8 perusahaan dengan teknik pengambilan sample yang dipergunakan dalam penelitian ini adalah Non Probability sampling dengan sampling jenuh. Dengan demikian maka populasi perusahaan otobus pariwisata di kota Denpasar sebanyak 8 perusahaan akan diteliti sebagai sampel dengan jumlah total 123 karyawan sebagai responden. Metode pengumpulan data yang digunakan dalam penelitian ini adalah kuesioner dan diukur menggunakan skala likert dengan skala 1-5. Teknik analisis data yang digunakan untuk menguji hipotesis yang diajukan dalam 
penelitian ini adalah teknik analisis regresi linier berganda. Dalam penelitian ini analisis regresi linear berganda dilakukan untuk mengetahui pengaruh implementasi 4 aspek yang ada pada total quality management terhadap kinerja manajerial perusahaan.

\section{HASIL DAN PEMBAHASAN}

Responden dari penelitian yang dilakukan ini adalah sebanyak 123 karyawan dari 8 perusahaan otobus pariwisata yang ada di Kota Denpasar. Berdasarkan hasil penelitian yang dilakukan terhadap karyawan pada perusahaan otobus pariwisata di Kota Denpasar. Selanjutnya, dilakukan uji validitas dengan mengkorelasikan antara skor faktor dengan skor total dan bila korelasi tiap faktor tersebut bernilai positif $(r>0,3)$. Adapun hasil uji menunjukkan bahwa seluruh koefisien korelasi dari indikator variabel yang diuji nilainya lebih besar dari 0,30 $(r>0,3)$. Hasil tersebut menunjukkan bahwa seluruh indikator yang terdapat pada penelitian ini terbukti valid. Hasil uji reliabilitas penelitian ini ditunjukkan dalam Tabel 2.

\section{Tabel 2. Hasil Uji Reliabilitas}

\begin{tabular}{lll}
\hline Variabel & Cronbach's Alpha & Keterangan \\
\hline Fokus pada Pelanggan $\left(\mathrm{X}_{1}\right)$ & 0,897 & Reliabel \\
Obsesi terhadap kualitas $\left(\mathrm{X}_{2}\right)$ & 0,945 & Reliabel \\
Perbaikan sistem secara berkesinambungan & 0,866 & Reliabel \\
$\left(\mathrm{X}_{3}\right)$ & & Reliabel \\
Keterlibatan dan Pemberdayaan Karyawan $\left(\mathrm{X}_{4}\right)$ & 0,916 & Reliabel \\
\hline Kinerja Manajerial $(\mathrm{Y})$ & 0,965 & \\
\hline
\end{tabular}

Sumber: Data Penelitian, 2020

Tabel 2, menunjukkan masing-masing nilai Cronbach's Alpha pada tiap instrumen tersebut lebih besar dari 0,60 (Cronbach's Alpha >0,60). Hal tersebut menunjukkan bahwa seluruh instrumen reliabel sehingga dapat digunakan untuk melakukan penelitian. Statistik deskriptif digunakan untuk memberikan gambaran atau deskriptif suatu data yang dilihat dari nilai rata-rata (mean), nilai minimum, nilai maksimum, dan nilai dari data penelitian. Hasil dari pengujian statistik deskriptif dari masing-masing variabel penelitian disajikan pada Tabel 3, sebagai berikut.

Tabel 3. Hasil Uji Statistik Deskriptif

\begin{tabular}{|c|c|c|c|c|c|}
\hline Variabel & $\mathrm{N}$ & Minimum & Maximum & Mean & Std. Deviation \\
\hline Fokus pada Pelanggan & 123 & 18 & 38 & 28.24 & 5.009 \\
\hline Obsesi terhadap kualitas & 123 & 10 & 25 & 17.25 & 3.396 \\
\hline $\begin{array}{l}\text { Perbaikan sistem secara } \\
\text { berkesinambungan }\end{array}$ & 123 & 8 & 22 & 17.49 & 3.194 \\
\hline $\begin{array}{l}\text { Keterlibatan dan } \\
\text { Pemberdayaan Karyawan }\end{array}$ & 123 & 12 & 40 & 26.16 & 6.328 \\
\hline Kinerja Manajerial & 123 & 18 & 40 & 29.30 & 5.897 \\
\hline
\end{tabular}

Sumber: Data Penelitian, 2020

Berdasarkan hasil uji statistik deskriptif Tabel 3, dapat dijelaskan beberapa hal yaitu variabel fokus pada pelanggan memiliki nilai minimum sebesar 18 dan nilai maksimum sebesar 38. Nilai rata-rata sebesar 28,24 menunjukkan bahwa fokus pada pelanggan berpengaruh terhadap kinerja manajerial perusahaan serta penyimpangan nilai rata-ratanya ditunjukkan 
melalui angka pada standar deviasi sebesar 5,009, variabel obsesi terhadap kualitas memiliki nilai minimum sebesar 10 dan nilai maksimum sebesar 25 . Nilai rata-rata sebesar 17,25 menunjukkan bahwa obsesi terhadap kualitas berpengaruh terhadap kinerja manajerial perusahaan serta penyimpangan nilai rata-ratanya ditunjukkan melalui angka pada standar deviasi sebesar 3,396, variabel perbaikan sistem secara berkesinambungan memiliki nilai minimum sebesar 8 dan nilai maksimum sebesar 22. Nilai rata-rata sebesar 17,49 menunjukkan bahwa perbaikan sistem secara berkesinambungan berpengaruh terhadap kinerja manajerial perusahaan serta penyimpangan nilai rata-ratanya ditunjukkan melalui angka pada standar deviasi sebesar 3,194, variabel keterlibatan dan pemberdayaan karyawan memiliki nilai minimum sebesar 12 dan nilai maksimum sebesar 40. Nilai rata-rata sebesar 26,16 menunjukkan bahwa keterlibatan dan pemberdayaan karyawan berpengaruh terhadap kinerja manajerial perusahaan serta penyimpangan nilai rata-ratanya ditunjukkan melalui angka pada standar deviasi sebesar 6,328, variabel kinerja manajerial memiliki nilai minimum sebesar 18 dan nilai maksimum sebesar 40. Nilai ratarata sebesar 29,30 dengan penyimpangan nilai rata-ratanya ditunjukkan melalui angka pada standar deviasi sebesar 5,897.

Suatu model regresi linear berganda secara teoritis akan menghasilkan nilai parameter penduga yang tepat bila memenuhi persyaratan asumsi klasik regresi, yaitu: uji normalitas, multikolinearitas, dan heteroskedastisitas. Adapun hasil uji Kolmogorov-Smirnov dapat ditampilkan dalam Tabel 4.

Tabel 4. Hasil Uji Normalitas

Unstandardized Residual

\begin{tabular}{ll}
\hline $\mathrm{N}$ & 123 \\
Kolmogorov-Smirnov Z & 0,668 \\
Asymp. Sig. (2-tailed) & 0,764 \\
\hline
\end{tabular}

Sumber: Data Penelitian, 2020

Berdasarkan hasil uji normalitas yang ditampilkan pada Tabel 4, tersebut menunjukkan bahwa besarnya nilai signifikansi sebesar 0,764. Karena nilai signifikansi uji Kolmogorov-Smirnov lebih dari 0,05 maka dapat disimpulkan bahwa model persamaan regresi tersebut berdistribusi normal.

Tabel 5. Uji Multikolinearitas

\begin{tabular}{lll}
\hline Variabel & Collinearity Statistics & \\
\cline { 2 - 3 } & Tolerance & VIF \\
\hline Fokus pada Pelanggan & 0.942 & 1.062 \\
Obsesi terhadap kualitas & 0.957 & 1.045 \\
Perbaikan sistem secara & 0.950 & 1.053 \\
berkesinambungan & & 1.097 \\
Keterlibatan dan Pemberdayaan & 0.912 & \\
Karyawan & &
\end{tabular}

Sumber: Data Penelitian, 2020

Uji multikolinearitas dilakukan untuk menguji apakah terdapat korelasi yang sempurna antar variabel bebas yang digunakan pada penelitian ini. Pengujian multikolinearitas dilakukan dengan menganalisis nilai tolerance dan nilai VIF. Berdasarkan Tabel 5, ditunjukkan bahwa tidak terdapat variabel bebas yang memiliki nilai tolerance kurang dari 0,10 dan juga tidak ada variabel bebas 
yang memiliki nilai VIF lebih dari 10. Maka dari pada itu model regresi bebas dari gejala multikolinearitas. Uji heteroskedastisitas ini bertujuan untuk mengetahui apakah dalam model regresi terjadi ketidaksamaan varians dari residual satu pengamatan ke pengamatan lain yang dilakukan dengan uji Glejser.

Tabel 6. Hasil Uji Heteroskedastisitas

\begin{tabular}{lcl}
\hline Variabel & $\mathrm{T}$ & Sig. \\
\hline Fokus pada Pelanggan & -0.462 & 0.645 \\
Obsesi terhadap kualitas & 1.414 & 0.160 \\
Perbaikan sistem secara & -1.113 & 0.268 \\
berkesinambungan & 0.193 \\
\hline
\end{tabular}

Sumber: Data Penelitian, 2020

Berdasarkan Tabel 6, tersebut, ditunjukkan bahwa masing-masing model memiliki nilai signifikansi lebih besar dari 0,05. Hal ini menunjukkan bahwa tidak terdapat pengaruh antara variabel bebas terhadap absolute residual. Dengan demikian, model yang dibuat tidak mengandung gejala heteroskedastisitas. Model analisis regresi linear berganda digunakan untuk mendapat koefisien regresi yang akan menentukan apakah hipotesis yang dibuat akan diterima atau ditolak.Hasil analisis ini mengacu pada hasil pengaruh variabel fokus pada pelanggan $\left(X_{1}\right)$, variabel Obsesi terhadap kualitas $\left(X_{2}\right)$, variabel perbaikan sistem secara berkesinambungan $\left(X_{3}\right)$ variabel keterlibatan dan pemberdayaan karyawan $\left(\mathrm{X}_{4}\right)$ terhadap kinerja manajerial $(\mathrm{Y})$ pada perusahaan otobus pariwisata di Kota Denpasar. Adapun hasil analisis regresi dengan program Statitical Pacage of Social Science (SPSS) versi 21.0 for Windows dapat dilihat pada Tabel 7. berikut.

Tabel 7. Rangkuman Hasil Analisis Regresi Linear Berganda

\begin{tabular}{|c|c|c|c|c|c|}
\hline \multirow{2}{*}{ Model } & \multicolumn{2}{|c|}{$\begin{array}{l}\text { Unstandardized } \\
\text { Coefficients }\end{array}$} & $\begin{array}{c}\text { Standardized } \\
\text { Coefficients }\end{array}$ & \multirow[t]{2}{*}{$\mathrm{t}$} & \multirow[t]{2}{*}{ Sig. } \\
\hline & $\mathrm{B}$ & Std. Error & Beta & & \\
\hline (Constant) & -3.990 & 3.280 & & -1.216 & 0.226 \\
\hline Fokus pada Pelanggan & 0.283 & 0.078 & 0.240 & 3.637 & 0.000 \\
\hline $\begin{array}{l}\text { Obsesi terhadap } \\
\text { kualitas }\end{array}$ & 0.645 & 0.114 & 0.372 & 5.677 & 0.000 \\
\hline $\begin{array}{l}\text { Perbaikan sistem secara } \\
\text { berkesinambungan }\end{array}$ & 0.266 & 0.121 & 0.144 & 2.193 & 0.030 \\
\hline $\begin{array}{l}\text { Keterlibatan dan } \\
\text { Pemberdayaan } \\
\text { Karyawan }\end{array}$ & 0.364 & 0.062 & 0.391 & 5.829 & 0.000 \\
\hline
\end{tabular}

Berdasarkan Tabel 7, dapat ditulis persamaan regresi linear berganda sebagai berikut.

$$
Y=-3,990+0,283 X 1+0,645 X 2+0,266 X 3+0,364 X 4+\varepsilon
$$


Dimana :

$\mathrm{Y}=$ Kinerja Manajerial

$\mathrm{X} 1=$ Fokus pada Pelanggan

$\mathrm{X} 2=$ Obsesi terhadap kualitas

$\mathrm{X} 3=$ Perbaikan sistem secara berkesinambungan

X4 = Keterlibatan dan Pemberdayaan Karyawan

Analisis derteminasi dilakukan untuk mengetahui sejauh mana variasi variabel bebas yaitu $\mathrm{X}_{1}, \mathrm{X}_{2}, \mathrm{X}_{3}, \mathrm{X}_{4}$ terhadap variabel $(\mathrm{Y})$.

Tabel 8. Analisis Determinasi

\begin{tabular}{lllll}
\hline Model & $\mathrm{R}$ & R Square & Adjusted R Square & $\begin{array}{l}\text { Std. Error of the } \\
\text { Estimate }\end{array}$ \\
\hline 1 & $0.718^{\mathrm{a}}$ & 0.516 & 0.500 & 4.170 \\
\hline
\end{tabular}

Sumber: Data Penelitian, 2020

Berdasarkan Tabel 8, tersebut dapat diketahui bahwa nilai $r$ square $\left(\mathrm{r}^{2}\right)=$ 0,516 . Berdasarkan hasil tersebut diketahui bahwa nilai $\mathrm{R}^{2}=51,6$ persen, yang berarti bahwa sebesar 51,6 persen kinerja manajerial pada perusahaan otobus pariwisata di Kota Denpasar dipengaruhi oleh variabel fokus pada pelanggan $\left(X_{1}\right)$, obsesi terhadap kualitas $\left(X_{2}\right)$, perbaikan sistem secara berkesinambungan $\left(X_{3}\right)$, keterlibatan dan pemberdayaan karyawan $\left(X_{4}\right)$, dan sisanya sebesar 48,4 persen dipengaruhi oleh variabel lain yang tidak diteliti pada penelitian ini.

Uji kelayakan model regresi bertujuan untuk mengetahui apakah semua variabel bebas yang diidentifikasi (fokus pada pelanggan, obsesi terhadap kualitas, perbaikan sistem secara berkesinambungan dan keterlibatan dan pemberdayaan karyawan) tepat digunakan memprediksi pengaruhnya terhadap kinerja manajerial. Uji ini sering juga disebut dengan uji $\mathrm{F}$. Hasil pengolahan data pada Tabel 9. dengan menggunakan program SPSS diperoleh nilai $\mathrm{F}_{\text {hitung }}$ sebesar 431,474 dengan signifikansi sebesar 0,000<0,05, maka dapat disimpulkan bahwa pada kelompok yang diuji memiliki perbedaan yang nyata (signifikan). Hasil ini mempunyai arti bahwa ada pengaruh signifikan antara fokus pada pelanggan, obsesi terhadap kualitas, perbaikan sistem secara berkesinambungan dan keterlibatan dan pemberdayaan karyawan secara simultan terhadap kinerja manajerial. Tabel 9, menunjukkan hasil perhitungan uji $\mathrm{F}$ dengan menggunakan SPSS 21.

Tabel 9. Hasil Uji F

Model Sum of Squares Df $\quad$ Mean Square F $\quad$ Sig.

\begin{tabular}{lllllll}
\hline & Regression & 2189.587 & 4 & 547.397 & 31.474 & $0.000^{\mathrm{b}}$ \\
1 & Residual & 2052.283 & 118 & 17.392 & & \\
& Total & 4241.870 & 122 & & & \\
\hline
\end{tabular}

Sumber: Data Penelitian, 2020

Uji hipotesis (uji t) digunakan untuk menguji pengaruh masing-masing variabel bebas (variabel fokus pada pelanggan, variabel obsesi terhadap kualitas, perbaikan sistem secara berkesinambungan, dan keterlibatan dan pemberdayaan 
karyawan) terhadap variabel terikat (kinerja manajerial). Tabel 10, menunjukkan hasil perhitungan uji t dengan menggunakan SPSS 21.

Tabel 10. Hasil Uji t

\begin{tabular}{lcc}
\hline Variabel & Unstandardized Coefficients Beta & Sig. \\
\hline Fokus pada Pelanggan & 0,283 & 0,000 \\
Obsesi terhadap kualitas & 0,645 & 0,000 \\
$\begin{array}{l}\text { Perbaikan sistem secara } \\
\text { berkesinambungan }\end{array}$ & 0,266 & 0,030 \\
Keterlibatan dan Pemberdayaan & 0,364 & 0,000 \\
Karyawan & & \\
\hline
\end{tabular}

Sumber: Data Penelitian, 2020

Kriteria pengujian untuk menjelaskan interpretasi pengaruh antar masing-masing variabel yakni apabila nilai signifikansi $<0,05$ maka hipotesis diterima. Sebaliknya, jika nilai signifikansi $>0,05$ maka hipotesis ditolak.

Berdasarkan pengolahan data, dihasilkan tingkat signifikansi 0,000 0,05. Berdasarkan nilai pengujian tersebut, dapat dilihat dengan statistik bahwa uji jatuh pada penolakan $\mathrm{H}_{0}$ ditolak dan $\mathrm{H}_{1}$ diterima untuk hipotesis pertama. Hal tersebut menyatakan penerimaan hipotesis yang bahwa terdapat pengaruh positif dan signifikan antara fokus pada pelanggan terhadap kinerja manajerial pada perusahaan otobus pariwisata di Kota Denpasar. Koefisien variabel X1 adalah positif 0,283 artinya fokus pada pelanggan berpengaruh positif terhadap kinerja manajerial. Apabila fokus pada pelanggan meningkat maka kinerja manajerial akan meningkat sebesar 0,283. Pelanggan merupakan orang yang harus dilayani oleh penjual, baik jasa maupun barang. Setiap organisasi perusahaan harus mengetahui, mengidentifikasi, dan menganalisis kebutuhan dan harapan pelanggan agar bisa memuaskannya. Dimana produk/jasa yang dibuat atau diberikan haruslah sesuai dengan keinginan para pelanggan. Kepuasan pelanggan merupakan salah satu indikator penting untuk mengukur kesehatan suatu perusahaan (Pratama \& Maghfiroh, 2016). Karena terdapat korelasi yang sangat kuat antara tingginya tingkat kepuasan pelanggan dan tingginya tingkat loyalitas mereka, yang pada akhirnya dapat meningkatkan profitabilitas perusahaan (Rangkuti, 2010).

Berdasarkan pengolahan data, dihasilkan tingkat signifikansi 0,000< 0,05. Berdasarkan nilai pengujian tersebut, dapat dilihat dengan statistik bahwa uji jatuh pada penolakan $\mathrm{H}_{0}$ ditolak dan $\mathrm{H}_{1}$ diterima untuk hipotesis kedua. Hal tersebut menyatakan penerimaan hipotesis yang bahwa terdapat pengaruh positif dan signifikan antara terhadap kinerja manajerial pada perusahaan otobus pariwisata di Kota Denpasar. Koefisien variabel X2 adalah positif 0,645, artinya obsesi terhadap kualitas berpengaruh positif terhadap kinerja manajerial. Apabila obsesi terhadap kualitas meningkat, maka kinerja manajerial akan meningkat sebesar 0,645. Kualitas produk atau jasa yang dihasikan baik maka akan memberikan kesan baik pula pada pelanggan. Mutu perusahaan harus ditingkatkan agar produk atau jasa yang ditawarkan memiliki kualitas yang baik dan bisa memenuhi harapan atau keinginan pelanggan (Jusuf, 2013), (Kurniawan et al., 2007), dan (Ramadhan \& Santosa, 2017). 
Berdasarkan pengolahan data, dihasilkan tingkat signifikansi 0,030 <0,05. Berdasarkan nilai pengujian tersebut, dapat dilihat dengan statistik bahwa uji jatuh pada penolakan $\mathrm{H}_{0}$ ditolak dan $\mathrm{H}_{1}$ diterima untuk hipotesis ketiga. Hal tersebut menyatakan penerimaan hipotesis yang bahwa terdapat pengaruh positif dan signifikan antara perbaikan sistem secara berkesinambungan terhadap kinerja manajerial pada perusahaan otobus pariwisata di Kota Denpasar. Koefisien variabel X3 adalah positif 0,266 artinya perbaikan sistem secara berkesinambungan berpengaruh positif terhadap kinerja manajerial. Apabila perbaikan sistem secara berkesinambungan meningkat maka kinerja manajerial akan meningkat sebesar 0,266. Setiap produk atau jasa dihasilkan dengan memanfaatkan proses-proses tertentu di dalam suatu sistem atau lingkungan. Oleh karena itu sistem yang ada perlu diperbaiki secara terusmenerus agar kualitas yang dihasilkan dapat terus meningkat. Perbaikan secara terus-menerus harus dilakukan perusahaan seiring dengan perkembangan informasi dan kebutuhan pelanggan. Perbaikan secara berkala di segala bidang yang rutin dilakukan perusahaan dapat meningkatkan kinerja manajerial. Peningkatan kinerja manajerial pada akhirnya dapat meningkatkan kualitas produk yang berujung pada peningkatan laba perusahaan dan akan berdampak langsung terhadap kinerja manajerial perusahaan (Meidiyana et al., 2014) dan (Tertius \& Christiawan, 2015).

Berdasarkan pengolahan data SPSS dihasilkan tingkat signifikansi 0,000< 0,05. Berdasarkan nilai pengujian tersebut, dapat dilihat dengan statistik bahwa uji jatuh pada penolakan $\mathrm{H}_{0}$ ditolak dan $\mathrm{H}_{1}$ diterima untuk hipotesis keempat. Hal tersebut menyatakan penerimaan hipotesis yang bahwa terdapat pengaruh positif dan signifikan antara keterlibatan dan pemberdayaan karyawan terhadap kinerja manajerial pada perusahaan otobus pariwisata di Kota Denpasar. Koefisien variabel X4 adalah positif 0,364, artinya keterlibatan dan pemberdayaan karyawan berpengaruh positif terhadap kinerja manajerial. Apabila keterlibatan dan pemberdayaan karyawan meningkat, maka kinerja manajerial akan meningkat sebesar 0,364.

\section{SIMPULAN}

Berdasarkan hasil penelitian yang telah diperoleh melalui pengujian statistik dan pembahasan. Didapatkan kesimpulan hasil yaitu terdapat pengaruh positif dan signifikan antara fokus pada pelanggan terhadap kinerja manajerial pada perusahaan otobus pariwisata di Kota Denpasar. Hal ini berarti semakin tingginya fokus pada pelanggan, maka akan meningkatkan kinerja manajerial. Terdapat pengaruh positif dan signifikan antara obsesi terhadap kualitas terhadap kinerja manajerial pada perusahaan otobus pariwisata di Kota Denpasar. Hal ini berarti semakin tingginya obsesi terhadap kualitas, maka akan meningkatkan kinerja manajerial. Terdapat pengaruh positif dan signifikan antara perbaikan sistem secara berkesinambungan terhadap kinerja manajerial pada perusahaan otobus pariwisata di Kota Denpasar. Hal ini berarti semakin tingginya perbaikan sistem secara berkesinambungan, maka akan meningkatkan kinerja manajerial. Terdapat pengaruh positif dan signifikan antara keterlibatan dan pemberdayaan karyawan terhadap kinerja manajerial pada perusahaan otobus pariwisata di Kota Denpasar. Hal ini berarti semakin tingginya 
keterlibatan dan pemberdayaan karyawan, maka akan meningkatkan kinerja manajerial.

\section{REFERENSI}

Almansour, Y. M. (2012). The Impact Of Total Quality Management Components On Small And Medium Enterprises' Financial Performance In Jordan. International Refereed Research Journal.

Efendi, P., \& Mandala, K. (2018). Pengaruh Implementasi Total Quality Management Terhadap Kepuasan Pelanggan Pada Perusahaan Barjaz Di Denpasar. E-Jurnal Manajemen Universitas Udayana. https:// doi.org/10.24843/ejmunud.2018.v7.i03.p19

Heavey, C., Ledwith, A., \& Murphy, E. (2014). Introducing a new continuous improvement framework for increased organisational return on investment. TQM Journal. https:// doi.org/10.1108/TQM-06-2013-0065

Irmadhani, A., Atika, D., \& Junaidi, L. D. (2019). Pengaruh Penerapan Total Quality Management dan Keunggulan Bersaing terhadap Kinerja Manajerial. Jurnal Warta, 62, 54-67.

Jusuf, R. S. (2013). Analisis Pengaruh Tqm, Sistem Pengukuran Kinerja Dan Reward Terhadap Kinerja Manajerial. Jurnal Riset Ekonomi, Manajemen, Bisnis Dan Akuntansi. https:// doi.org/10.35794/emba.v1i3.1870

Kinasih, H. P. (2017). Pengaruh Total Quality Management dan Ketidakpastian Lingkungan terhadap Kinerja Manajerial pada Perusahaan Manufaktur di Surabaya. Jurnal Akuntansi STIE Perbanas Surabaya.

Kurniawan, I., Santoso, S. B., \& Dwiyanto, B. M. (2007). Analisis Faktor-Faktor Yang Mempengaruhi Minat Beli Ulang Produk Serta Dampaknya Terhadap Loyalitas Pelanggan (Studi Kasus Pada Produk Sakatonik Liver Di Kota Semarang). Studi Manajemen Dan Organisasi Faculty of Economics and Business Diponegoro University, 4(2), 65-75.

Lamato, B., Jan, A., \& Karuntu, M. (2017). Analisis Total Quality Management ( Tqm ) Terhadap Kinerja Manajerial Pada Pt . Asegar Murni Jaya Desa Tumaluntung Kab. Minahasa Utara. Jurnal Emba.

Meidiyana, A. V., Rutiyaningsih, S., \& Immanuela, I. (2014). Pengaruh Total Quality Management (TQM) Terhadap Kinerja Manajerial dengan Sistem Penhargaan (Reward) Sebagai Variabel Moderatin pada INKA (Persero) Madiun. Jurnal Riset Manajemen Dan Akuntansi.

Muhamad, A. (2015). Pengaruh Total Quality Management terhadap Kinerja Manajerial dengan Sistem Pengukuran Kinerja dan Sistem Penghargaan (Reward) sebagai Variabel Moderating pada PT. PLN DI PEKANBARU. JOM FEKON, 2(2). https:/ / doi.org/10.1017/CBO9781107415324.004

Oprime, P. C., Mendez, G. H., \& Pimenta, M. L. (2012). Continuus improvement: Critical factors in Brazilian industrial companies. International Journal of Productivity and Perfomance Management, 21-36.

Parwitasari, A. A. S. I. D., \& Wirasedana, I. W. P. (2018). Pengaruh Penerapan Total Quality Management, Komitmen Organisasi pada Kinerja Manajerial dengan Reward sebagai Variabel Moderasi. E-Jurnal Akuntansi, 25(3), 20722097,. https:// doi.org/10.24843/eja.2018.v25.i03.p17

Pratama, A. A. N., \& Maghfiroh, F. N. (2016). Pengaruh Total Quality 
Management (TQM) terhadap Kinerja Karyawan di BMT Taruna Sejahtera Ungaran, Jawa Tengah. Muqtasid: Jurnal Ekonomi Dan Perbankan Syariah, 7(1), 93. https://doi.org/10.18326/muqtasid.v7i1.93-117

Prayhoego, C., \& Devie. (2013). Analisa Pengaruh Total Quality Management Terhadap Keunggulan Bersaing dan Kinerja Perusahaan. Business Accounting Review, Vol. 1, 2013, 1(1-2), 15. https://doi.org/10.1016/01666851(92)90127-6

Psomas, E., Vouzas, F., \& Kafetzopoulos, D. (2014). Quality management benefits through the "soft" and "hard" aspect of TQM in food companies. TQM Journal. https:/ / doi.org/10.1108/TQM-02-2013-0017

Putri, I. G. A. M. A. D. (2008). Implikasi Riset Akuntansi Keperilakuan Terhadap Pengembangan Akuntansi Manajemen. Jurnal Ilmiah Akuntansi Dan Bisnis, $1-17$.

Ramadhan, A., G., dan Santosa, S., B. (2017). Analisis Pengaruh Kualitas Produk, Kualitas Pelayanan, dan Citra Merek terhadap Minat Beli Ulang pada Sepatu Nike Running di Semarang melalui Kepuasan Pelanggan sebagai Variabel Intervening. Diponegoro Journal Of Management, 6(1), 1-12.

Rangkuti, F. (2010). Spriritual Leadership in Business. PT. Gramedia Pustaka Utama.

Singkoh, A. F., Palandeng, I. D., \& Karuntu, M. M. (2018). Pengaruh Penerapan Total Quality Management (Tqm) Terhadap Kinerja Organisasi Di Puskesmas Paniki Bawah Kota Manado. Jurnal EMBA: Jurnal Riset Ekonomi, Manajemen, Bisnis Dan Akuntansi, 6(4), 4143 - 4152. https:// doi.org/10.35794/emba.v6i4.22245

Swari, N. P. L. R. I., \& Wirasedana, I. W. P. (2017). Pengatuh Sistem Penghargaan, Total Quality Management (TQM), Sistem Pengukuran Kinerja, Dan Ketidakpastian Lingkungan terhadap Kinerja Manajerial. E-Jurnal Akuntansi Universitas Udayana, 21(1), 830-856.

Tertius, M. A., \& Christiawan, Y. J. (2015). Pengaruh Good Corporate Governance terhadap Kinerja Perusahaan pada Sektor Keuangan. Business Accounting Rivew, 3(1), 223-232. 